\title{
British and European Citizenship: Entanglements through the Lens of Disability
}

\author{
Monika Baár and Paul van Trigt
}

As the process of Brexit has been unfolding, discussions on the UK's role in European history and politics have reaffirmed a narrative of an 'awkward relationship' or 'reluctant partnership'. Debates about the UK's role have focused on motivations by the UK government and certain key politicians, or the limitations of bureaucratic machineries and central issues of trade and border control. Arguments have often rested on an assumption concerning the exceptionality of the UK's history - whether because of its geographical location, historical institutions or the specific trajectory of its EU membership from the time of joining to the moment of the vote to leave. By contrast, British citizens usually only feature as 'misled subjects'; their agency and perspectives have been widely ignored. This essay argues for the need to pay more attention to historical and contemporary developments at the grassroots level, both in public discussions and in academic scholarship. 'The United Kingdom' and the British position in Europe cannot be reduced simply to governmental approaches and policies. Introducing this nuance may help to invigorate and add an alternative dimension to debates about Brexit, British exceptionalism and past and future UK-European relations.

At the centre of this piece are citizens with disabilities, estimated to comprise up to 20 per cent of the British population. Looking beyond the government and examining the United Kingdom and the European Union through the lens of disability challenges the assumption of British exceptionalism. It also reminds us that the views of British governments do not necessarily align with those of British citizens. While British governments were rarely supportive of (and frequently obstructed) European developments in the field of disability rights and policies, British disabled activists played a fundamental role in forcing the 'European ship of state' to reconsider the existing - often well-meaning, but somewhat paternalistic - attitudes and policies. Their input was indispensable for the creation of a new legal framework for disability.

People with disabilities remained nearly invisible in the debates about British relationships with Europe that preceded the Brexit referendum. Afterwards, in the efforts to draw up an inventory of the various areas of public life under threat as a result of Brexit, disabled rights have figured heavily. One lament includes the loss of British citizens' access to the European Social Fund, which provides support for disadvantaged groups for education, community services and independent living. The loss of British individuals' and NGOs' eligibility to apply for such funds will put more pressure on the public purse. Other concerns include the state of the National Health Service (NHS) more generally, which received a great deal of attention during the referendum campaign, and the false promises made by Brexiteers became one of its most frequently quoted episodes. Not only was the promised financial boost as a result of Brexit unmasked as fiction, but the fears about shortages of NHS personnel accentuated as a result of a large drop in nursing applications. This came on top of an already existing shortage of personnel for outpatient care, as a result of which disabled people who are currently able to live at home may be forced to slide back to nursing homes. One consequence of the referendum result has been that the UK's dependence on a broad pool of European and non-European workers has 
become clear even to those who were oblivious of this fact: few state institutions exist that are more international than the National Health Service.

In addition to these practical problems of staffing, and access to and levels of care, other fundamental issues concern more general rights and representations. The Withdrawal Agreement removes the link to the EU's Charter of Fundamental Rights from UK legislation. The UK Equality Act is not equivalent to this Charter: it is not a constitutional piece of legislation, which means that any of its constituent elements may be scrapped. While the legal framework provided by the EU is not in itself a guarantee of implementation 'on the ground', it has become a safety net below which rights are not permitted to fall. As such it has served as an important accountability mechanism for disabled people in their struggles against societal exclusion. Once that protection and accountability is removed there is no guarantee to stop another government rolling back those rights. Although the UK is bound by international law by the United Nations' Convention on the Rights of Persons with Disabilities, this is not incorporated into domestic law. Moreover, the UK has been breaching those rights so frequently that in August 2017 nearly eighty recommendations were made to the British government, and sharp criticism was levelled at the government's failure to assess the impact of austerity on disabled people.

Importantly, there is a long history of public campaigning and activism that connects the UK with the EU and Europe, and that has had some tangible results. The legal provisions which turned the European Union into a more inclusive space were to a significant extent the result of the lobbying of British activists. They began their activities in the 1960s in the realm of domestic policy, by advocating the introduction of measures to reduce poverty, such as a comprehensive disability income. Their work became particularly pertinent in subsequent decades, particularly in the course of the 1980s, when the new Tory government's policies reshaped the welfare landscape. The new, individualistic rhetoric, based on the tenets of neoliberalism, emphasised 'independence', an objective which was used as a pretext for the cutting of welfare services, privatisation and the 'responsibilisation' of citizens. As the state was rolling back in this way, the vocal grassroots movement started to expand. One of the novelties in this group's agenda was that they did not accept the traditional perception of disabled people as objects of charity and pity; instead, they demanded rights.

With the UK's entry into the European Community in 1973 British disabled activists became confronted with somewhat condescending attitudes towards disabled citizens. In the documents of the European Social Fund they were typically viewed as a significant economic burden on the welfare state who did not contribute to the production process, stood below the standard of average consumers, did not pay taxes and accounted for a considerable share of the social budget. Adopting this perspective, social policy documents viewed disability as an individual medical deficit. Hence, the majority of efforts revolved around rehabilitation and reintegration into the labour market. From the 1980s onwards, however, these perceptions shifted in a significant way, as the documents of the Social Fund from this period demonstrate. At the core of this transformation was the replacement of the 'medical model' of disability with the so-called 'social model' (an expression coined by British activist Mike Oliver), which understood disability not as a health deficit but as a social construct. According to this model, it was not so much the individual's bodily or mental impairment, but the discriminatory social attitudes and physical barriers that prevented disabled people from participating fully in the community. It was therefore society that needed to be adjusted if improvements were to be made. While the social model was certainly not the exclusive legacy of British activists, there is no doubt that their activities had a significant impact on the transformation of disability policies and legal developments at the European level.

One instance of that impact became evident on 3 December 1993, when the building of the newly opened European Parliament in Brussels became witness to a spectacular and somewhat unusual scene: 440 disabled people from all over Europe entered the huge debating chamber and seventy-two of them took the floor and gave short talks about their experiences of segregation, 
discrimination and abuse. The occasion was the first Day of Disabled People and the unusual guests came to affirm their human rights under the European Convention. The author of the draft resolution, and one of the main organisers of the event was a British activist, Rachel Hurst. The idea to mark the day with a 'spectacle' at the European Parliament was the brainchild of Arthur Verney, who was then president of the British Deaf Association. The event was rather difficult to organise and required persistence: on two previous occasions, Hurst's request to use the building had been turned down by the College of Questors, the Parliament's gatekeepers. As she later recalled, the gatekeeprs did not want to let them in to the building because they were afraid that the 'crippled guests' were going to urinate on the MPs' seats. Clearly, the slogan of the disability movement: 'nothing about us without us' was not yet familiar to the personnel of the European Parliament.

Another example of the crucial and contradictory nature of the British contribution to European developments concerns Article 13 on non-discrimination of the Amsterdam Treaty of 1996. In the history of the Amsterdam Treaty, the UK - or more precisely, the UK government is remembered to have played a role that was far from being constructive. This is also true for the specific case of Article 13. Its inclusion received widespread support during the negotiations, with only one dissenting voice, generally presumed to be the British Conservative Government of the time. When, later, non-discrimination on grounds of disability was developed into a European legal principle, the UK government's attitude remained equally uncooperative. But once again, the perspective of the British government was not identical to that of the British people: paradoxically, one of the main architects of Article 13 was Rachel Hurst, a British citizen, representing a sizeable group of her compatriots.

What conclusions can we draw from these episodes? UK disability policies have evolved in tandem with European policies, and are as a result inextricably intertwined with them. If there is anything distinctive about the UK then it is precisely the nature of this entanglement. While the UK government acted as a reluctant partner vis-à-vis the EU, often questioning the legitimacy of European developments, British disabled activists were actively engaged in creating new norms of European social citizenship. 'The United Kingdom' and British involvements with the rest of Europe therefore cannot be encapsulated by the actions of its government and official relationships with the EU institutions alone. An important set of British-European interactions were and are represented by British citizen-activists, such as those campaigning for disability rights discussed in this essay. It is an irony of fate that those who have fought to make the EU a better place for people with disabilities will lose access to the achievements which are, to a certain extent, their own. Instead of continuing to work towards making the EU - and the UK within the EU - a more inclusive place, they will now have to spend their energies to prevent the UK outside the EU from becoming a more exclusive one.

Cite this article: Baár, M. and van Trigt, P. 2019. British and European Citizenship: Entanglements through the Lens of Disability. Contemporary European History 28: 50-52, doi: 10.1017/S0960777318000796 